УДК 664.8/.9

DOI https://doi.org/10.32851/tnv-tech.2021.6.15

\title{
ДОСВІД ЗАСТОСУВАННЯ КУЛЬТИВОВАНИХ ГРИБІВ ПРИ ВИРОБНИЦТВІ М'ЯСО-РОСЛИННИХ КОНСЕРВІВ
}

\author{
Ряполова I.O. - кандидат сільськогосподарських наук, \\ доцент кафедри інженерії харчового виробництва \\ Херсонського державного аграрно-економічного університету \\ ORCID ID: 0000-0002-7672-6639 \\ Scopus-Author ID: 57207853973 \\ Верешко C. - студент магістратури \\ біолого-технологічного фракультету \\ Херсонського державного аграрно-економічного університету \\ ORCID ID: 0000-0001-8517-2490 \\ Радченко В. - студентка магістратури \\ біолого-технологічного фракультету \\ Херсонського державного аграрно-економічного університету \\ ORCID ID: 0000-0002-9641-2127
}

Стаття присвячена обтрунтуванню можливості введення у склад м'ясо-рослинних консервів культивованих грибів, а саме гливи звичайної. Дана рослинна сировина володіє иілим рядом корисних властивостей: $є$ низькокалорійним продуктом; джерелом калію; одним із найбагатших джерел ичинк, який сприяє підтримизі імунітету людини; замість глюкози глива містить манітол, тому діабетики можуть сміливо включати в свою дієту страви з гливи; велику кількість вітамінів групи В і D; багато клітковини, яка покращує роботу травного тракту і нормалізує його мікрофлору.

Теоретичні розрахунки та практичні напрацюювання дозволили розробити рецептуру м'ясо-рослинних консервів та запропонувати технологічну схему. Для порівняння використовували різні співвідношення м'яса свинини і грибів із роду глива, які були оброблені бланшуванням при температурі $80^{\circ}$ С протягом 5 хвилин.

Аналіз сенсорної та профільної оцінки розробленої продукції свідчить про досить привабливі і гармонійні поєднання компонентів консерви у зразку №1, де вміст грибної сировини становить 23\%. Даний варіант мав запах і смак властивий тушкованій свинині з незначним присмаком грибів, рівномірно розподілені шматочки м'яса $і$ грибів $і$ невелику кількість желеподібного бульйону. Встановлено, щз м'ясо-рослинні консерви першого варіанту де кількість рослинних компонентів становить 23\%, за нутрієнтним складом трохи поступаються контрольному зразку, але мають вищі показники ніж у другому варіанті (де 38\% м'ясної сировини замінено грибами) за кількістю вітамінів ( $B_{1}, B_{3}, B_{6}, B_{12}$, Д, E), мінералів (Na, P, Se, Zn). 3 точки зору макро- і мікронутрієнтного складу співвідношення м'ясної сировини до рослинної 65\% / 23\% є найбільш оптимальним.

Ключові слова: м'ясо-рослинні консерви, органолептичні показники, профільна оцінка, м'ясо охолоджене, м'ясо дефростоване, глива звичайна, нутрієнтний склад.

Ryapolova I.O., Vereshko S., Radchenko V. Experience of using cultivated mushrooms in the production of canned meat and vegetables

The article is devoted to the substantiation of the possibility of introducing cultivated mushrooms, namely oyster mushrooms, into the composition of canned meat and vegetables. This vegetable raw material has a number of useful properties: it is a low-calorie product; rich source of potassium; one of the richest sources of zinc, which helps maintain human immunity; instead of glucose, oyster mushrooms contain mannitol, so diabetics can safely include oyster mushrooms in their diet; a large number of vitamins $B$ and $D$; a lot of fiber, which improves the digestive tract and normalizes its microflora.

Theoretical calculations and practical developments have made it possible to develop a recipe for canned meat and vegetables and to propose a technological scheme. For comparison, different ratios of meat and mushrooms of the fungus genus were used, which were blanched at $80^{\circ} \mathrm{C}$ for 5 minutes. 
Analysis of sensory and profile evaluation of developed products shows a very attractive and harmonious combination of canned ingredients in sample №1, where the content of fungal raw materials is $23 \%$. This variant had the smell and taste of stewed pork with a slight taste of mushrooms, evenly distributed pieces of meat and mushrooms and a small amount of jelly-like broth. It was found that canned meat and vegetable variant I, where the number of plant components is $23 \%$, is slightly inferior to the control sample in terms of nutritional composition, but has higher rates than in the second variant (where $38 \%$ of raw meat is replaced by mushrooms). B1, $B 3, B 6, B 12, D, E)$, minerals (Na, P, Se, Zn). From the point of view of macro- and micronutrient composition, the ratio of raw meat to vegetable $65 \% / 23 \%$ is the most optimal.

Key words: canned meat and vegetables, organoleptic characteristics, profile assessment, chilled meat, defrosted meat, common oysters, nutrient composition.

Вступ. Збереження і зміцнення здоров'я людини за рахунок профілактики захворювань, обумовлених повноцінним і збалансованим харчуванням, формування розвинутої індустрії і інноваційних технологій виробництва харчових продуктів здорового харчування відносяться до основних пріоритетів держави.

У зв'язку із цим перед м'ясною промисловістю стоять завдання створення і збільшення випуску нових високоякісних і безпечних продуктів загального і спеціального призначення які містять широкий спектр фізіологічно затребуваних нутрієнтів і забезпечують прогнозовані властивості, конкурентоспроможність, соціально-економічну значущість і імпортозаміщення.

Постановка проблеми. Ми пропонуємо для створення функціональних властивостей м'ясо-рослинних консервів додати до свинини культивовані гриби, а саме гливу звичайну, яка володіє рядом корисних ознак:

1. Гриби гливи $є$ низькокалорійним продуктом. Ця якість може допомогти підтримувати оптимальну масу тіла тим людям, які прагнуть зниження власної ваги. Збільшення споживання гливи зробить харчування більш збалансованим. У Європі розроблено грибні дієти за участю страв із гливи із загальною енергетикою не більше 1100 ккал на день. Велика кількість клітковини у грибах дає відчуття ситості, незважаючи на низьку калорійність.

2. Гриби гливи є одним із найбагатших джерел цинку, який сприяє підтримці імунітету людини незалежно від його віку.

3. Глива є багатим джерелом калію, необхідний вміст якого в організмі покращує діяльність серця та нирок.

4. Замість глюкози глива містить манітол, тому діабетики можуть сміливо включати в свою дієту страви з гливи.

5. Глива містить велику кількість вітамінів групи В і D, які необхідні для підтримки здоров'я людини. Помірне щоденне споживання грибів забезпечить суттєву частку добової потреби людини у цих вітамінах.

6. Глива містить багато клітковини, яка покращує роботу травного тракту і нормалізує його мікрофлору.

7. Полісахариди та клітковина гливи є хорошими сорбентами і допомагають очищати організм від токсинів та важких металів.

У технології виробництва культивованих грибів $є$ певні переваги. До них відносять безвідходність і екологічність. Для їх вирощування яке можна здійснювати круглий рік у різних кліматичних умовах, використовують різні рослинні субстрати 3 відходів насінництва, харчових виробництв, лісопереробної галузі причому субстрат можна використовувати двічі. Після використання живильний субстрат може бути внесений у грунт як біологічне добриво під овочеві культури та плодові дерева, а також його використовують у якості корму для тварин. Глива є лідером серед культивованих грибів за кількістю субстратів на яких їі можна вирощувати. 
Хімічний склад культивованих грибів може бути різним, що пов'язано з великим різноманіттям живильних субстратів які використовують для вирощування гливи. Питаннями вивчення хімічного складу, вирощування, зберігання гливи займалося багато науковців $[1 ; 2 ; 3 ; 4]$.

Разом 3 тим, широке впровадження гливи у виробництво та просування іiі на споживчому ринку як екологічно чистого та корисного продукту обмежується відсутністю робіт, що висвітлюють наукові засади технології переробки грибів цього виду.

3 досвіду використання гливи звичайної відомо, що вона має дуже добрі технологічні властивості, володіє значною швидкістю росту, також відомо про ії лікувальні та профілактичні властивості, вона має виражені протипухлинні, радіопротекторні, антивірусні, гіпоглікемічні, імуномоделюючі властивості.

Але, поряд с тим необхідно відзначити, що обмежений термін придатності до споживання гливи, створює певні труднощі у потоковому виробництві м'ясних консервів з грибами без використання додаткових технологічних операцій. Тому розглядається можливість виробництва грибних напівфабрикатів. Ряд дослідників пропонують висушувати гриби і додавати до м'ясної сировини у вигляді порошку [5].

Мета досліджень. Метою досліджень $є$ обгрунтування можливості використання гливи звичайної у виробництві м'ясо-рослинних консервів та проведення досліджень основних властивостей консервованої продукції.

Аналіз останніх досліджень і публікацій. Виробництво м'ясних консервів займає власну, досить велику частку у харчовій галузі. Асортимент продукції представлений м'ясо-рослинними паштетами, м'ясом тушкованим, м'ясо-рослинними кашами та ін. Аналіз літературних джерел свідчить, що науковці технологи постійно вдосконалюють і пропонують нові рецептури даного виду продукції, додаючи до основної сировини (м'ясо, субпродукти ) рослинні компоненти, які володіють функціональними властивостями $[6 ; 7 ; 8]$. Створення нових технологій та рецептур комбінованих м'ясних виробів сприяє підвищенню якості напівфабрикатів у порівнянні з вихідною сировиною, що відбувається за рахунок механічної деструкції грубих волокон сполучної тканини м'яса, використання додаткових інгредієнтів та добавок які покращують органолептичні показники готових м'ясних продуктів. Розроблені комбіновані продукти відрізняються високою біологічною цінністю, збалансованим аміно-, жирнокислотним, вітамінним і мінеральним складом, мають гідні органолептичні характеристики і добре засвоюються організмом людини.

Виклад основного матеріалу дослідження. Враховуючі переваги гливи, було зроблено експериментальні проробки щодо використання грибів у якості рослинного компоненту при виробництві м'ясо-рослинних консервів. М'ясна і рослинна сировина, яку будемо використовувати повинна відповідати певним вимогам. На гливу звичайну розповсюджується ДСТУ 7786:2015 Гриби. Глива звичайна свіжа. Технічні умови, в яких вказано перелік допустимих речовин. Свинина має відповідати вимогам ДСТУ 7158:2010 М'ясо. Свинина в тушах і півтушах. Технічні умови.

Теоретичні розрахунки та практичні напрацювання дозволили розробити рецептуру м'ясо-рослинних консервів та запропонувати технологічну схему. Для порівняння використовували різні співвідношення м'яса і грибів із роду глива, які були оброблені бланшуванням при температурі 800С протягом 5 хвилин.

Хімічний аналіз свинини і гливи звичайної які будуть основною сировиною при створенні м'ясних готових страв з рослинними компонентами, свідчить про добрий баланс між складовими нутрієнтами (рис. 1). 

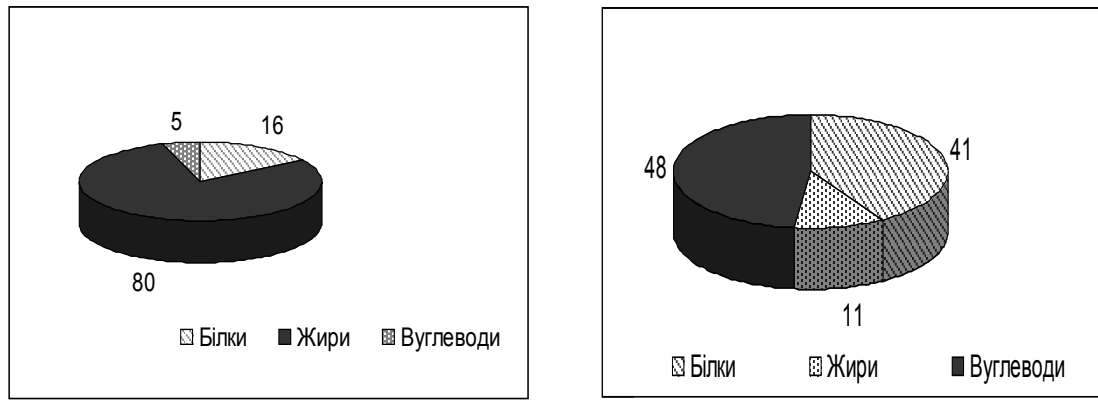

Рис. 1. Співвідношення основних нутрієнтів у свинині та у грибах

Як видно з діаграми співвідношення білків, жирів і вуглеводів у свинині становить $1: 2.2: 0.3$, грибах $-1: 0,2: 1$. Такі складові гливи звичайної як вуглеводи, клітковина можуть компенсувати надмірну кількість жиру що містить свинина, утворивши полікомпонентний комплекс. За рахунок введення грибів частково задовольнясться потреба у цинку і вітамінах групи В $\left(\mathrm{B}_{2}, \mathrm{~B}_{3}, \mathrm{~B}_{5}, \mathrm{~B}_{6}, \mathrm{~B}_{9}\right)$, вітаміні Д, Е, біотині.

За контроль під час моделювання рецептури і вибору оптимального співвідношення основних компонентів та складових обрано м'ясні консерви з гречаною крупою які виробляються в умовах дослідного підприємства. У рецептурі даних м'ясо-рослинних консервів міститься 65\% м'яса свинини і $23 \%$ гречаної крупи. Шляхом підбору було обрано два варіанти комбінацій вмісту грибів: у першому варіанті також додавали 23\% бланшованих подрібнених грибів гливи, у другому варіанті зменшили кількість м'яса до 50\% і збільшили кількість рослинного компоненту до $38 \%$.

Склад основної та допоміжної сировини у контрольному варіанті і модельних зразках наведено в таблиці 1.

Таблиця 1

Комбінації компонентів м'ясо-рослинних консервів

\begin{tabular}{|l|c|c|c|}
\hline $\begin{array}{c}\text { Компоненти м'ясо-рослинних } \\
\text { консервів, \% }\end{array}$ & $\begin{array}{c}\text { Каша гречана } \\
\text { зі свининою }\end{array}$ & Варіант I & Варіант II \\
\hline Свинина знежилована & 65 & 65 & 50 \\
\hline Гриби (глива звичайна) & - & 23 & 38 \\
\hline Крупа гречана & 23 & - & - \\
\hline Олія соняшникова рафінована & 5 & 5 & 5 \\
\hline Сіль кухонна харчова & 1,5 & 1,5 & 1,5 \\
\hline Цибуля свіжа & 5 & 5 & 5 \\
\hline Перець чорний мелений & 0,5 & 0,5 & 0,5 \\
\hline
\end{tabular}

Розробка технологічної схеми виробництва запропонованих м'ясо-рослинних консервів проводилася з урахуванням існуючої схеми виробництва контрольної продукції, а саме «Гречана каша зі свининою». Але при виробництві м'ясо-грибних консервів, є додаткова операції, що стосується підготовки грибів. Вони мають велику кількість води і закладати їх у банки необробленими не доречно, тому що це призведе до зменшення маси і утворення надмірної кількості бульйону. Отож, після інспекції та миття і перед подрібненням запропоновано попереднє бланшування 
грибів. Таку ж операцію включено i для м'ясної сировини (свинини). У експериментальних зразках моделювали різну величину шматочків м'яса і грибів.

Таким чином, технологічна схема виробництва м'ясо-рослинних консервів включає декілька операцій: приймання м'ясної сировини, зберігання, миття, інспектування, бланшування, подрібнення; приймання додаткової сировини (гриби, цибуля, спеціï), зберігання, миття грибів, інспектування, бланшування грибів, подрібнення, чищення та миття цибулі, iii подрібнення; приймання пакувальних матеріалів, зберігання, миття банок та кришок; закладання сировини у тару, стерилізація, маркування та витримка у термостатній кімнаті.

Вивчення органолептичних показників, фізико-хімічних, структурно-механічних характеристик дозволить дізнатися про вплив взаємодії різних видів компонентів консерви на якісні характеристики готової продукції. Органолептичну оцінку модельних зразків розробленої продукції здійснювали за 5-ти бальною шкалою комісією у складі 6 чоловік які володіють навиками дегустаторів і можуть сприймати відтінки запаху, смаку, кольору. У готових зразках визначали весь вміст консервів: зовнішній вигляд, як розподіляються між собою складові, колір, запах і аромат у холодному та підігрітому до $35^{\circ} \mathrm{C}$ стані, консистенцію (ніжність, соковитість, пружність, щільність, розсипчастість), смак. Органолептичні показники розробленої продукції і контрольного зразку наведені в таблиці 2.

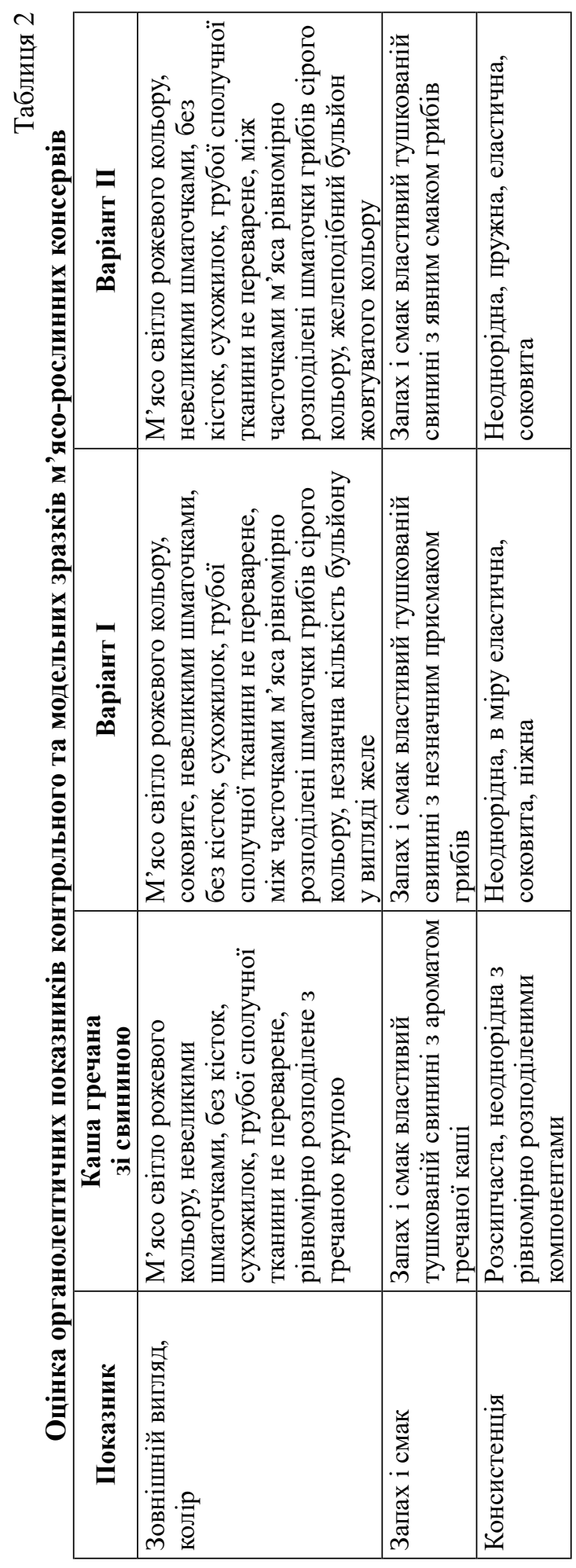


Для опрацювання органолептичних показників була використана сучасна методика сенсорного аналізу і проведено профілювання готової продукції. Це дало можливість здійснити порівняння показників між модельними зразками, розкладали їх на прості дескриптори і побудували профілограму (рис. 2).

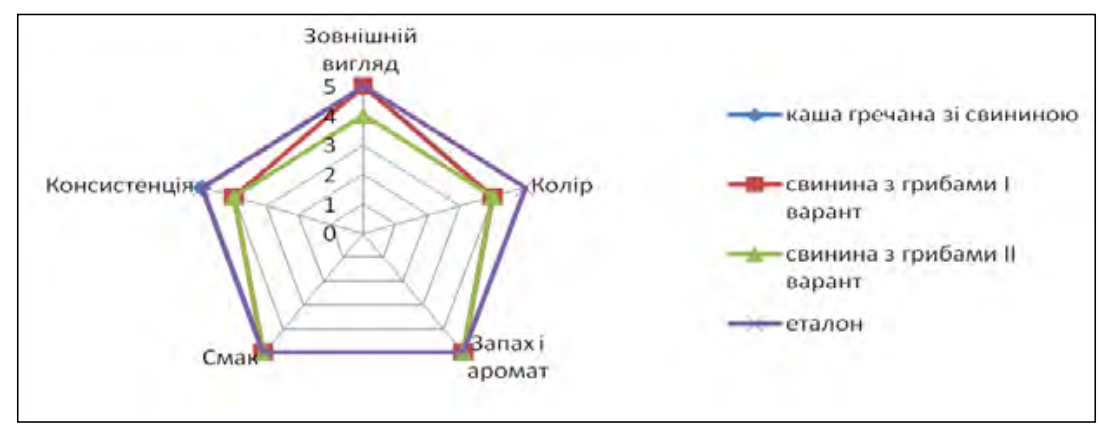

Рис. 2. Профільна оцінка м'ясо-рослинних консервів запропонованих варіантів

Аналіз сенсорної та профільної оцінки розробленої продукції свідчить про досить привабливі і гармонійні поєднання компонентів консерви у зразку № 1, де вміст грибної сировини становить $23 \%$. Даний варіант мав запах і смак властивий тушкованій свинині з незначним ароматом і присмаком грибів, рівномірно розподілені шматочки м'яса і грибів і невелику кількість желеподібного бульйону.

Другий запропонований варіант мав більше розбіжностей 3 контрольним зразком і еталонними значеннями. Він оцінений нижче за зовнішнім виглядом, кольором і консистенцією, що мабуть пов'язано з процентним співвідношенням м'ясної і рослинної сировини.

Аналіз хімічного складу готових модельних зразків, зроблений на підставі даних довіднику хімічного складу харчових продуктів [9] свідчить, що м'ясо-рослинні консерви I варіанту де кількість рослинних компонентів становить 23\%, за нутрієнтним складом трохи поступаються контрольному зразку, але мають вищі показники ніж у другому варіанті (де 38\% м'ясної сировини замінено грибами) за кількістю вітамінів (B1, B3, B6, B12, Д, Е), мінералів (Na, P, Se, Zn). Отже, співвідношення м'ясної сировини до рослинної 65 / 23\% є найбільш оптимальним з точки зору макро- і мікронутрієнтного складу.

Для отримання якісної і безпечної готової продукції необхідно мати якісну сировину яка відповідає санітарно-гігієнічним вимогам. Перед виготовленням модельних зразків розробленої продукції було проведено лабораторний аналіз м'ясної сировини. Визначено активну кислотність м'ясної сировини з охолодженого і дефростованого м'яса і м'ясо-грибної сировини, також оцінено ступінь свіжості м'яса в реакції з міді сульфатом у бульйоні (таблиця 3).

Отриманні значення $\mathrm{pH}$ та реакції з сульфатом міді свідчать, що м'ясо свинини отримане від здорових тварин, охолоджене і дефростоване м'ясо має показники, які відповідають нормативним показникам. М'ясо-грибна сировина має дещо вищі показники $\mathrm{pH}$, що властиво рослинній продукції, а саме грибам які вводяться до складу консервів.

Для встановлення безпечності сировини за мікробіологічним критерієм ми провели визначення кількості мезофільних аеробних та факультативно анаеробних мікроорганізмів (МАФАнМ) у 1 г м'яса свинини, грибах та спеціях які входять у рецептуру консервів шляхом висіву на МПА, бактерій групи кишкової палички 
Таблиця 3

Показники ступеню свіжості сировини для м'ясо-рослинних консервів

\begin{tabular}{|c|c|c|c|c|}
\hline \multirow[b]{2}{*}{ Показник } & \multicolumn{4}{|c|}{ Сировина } \\
\hline & $\begin{array}{c}\text { м'ясна } \\
\text { (охолоджене } \\
\text { м'ясо) }\end{array}$ & $\begin{array}{c}\text { м'ясна } \\
\text { (дефростоване } \\
\text { м'ясо) } \\
\end{array}$ & $\begin{array}{c}\text { м'ясо-грибна } \\
\text { з охолодженого } \\
\text { м'яса } \\
\end{array}$ & $\begin{array}{c}\text { м'ясо-грибна } \\
\text { зефростованого } \\
\text { м'яса }\end{array}$ \\
\hline Значення рН & $5,8 \pm 0,01$ & $6,0 \pm 0,01$ & $6,2 \pm 0,02$ & $6,4 \pm 0,01$ \\
\hline $\begin{array}{l}\text { Значення } \\
\text { реакції з міді } \\
\text { сульфатом }\end{array}$ & $\begin{array}{c}\text { м'ясний } \\
\text { бульйон } \\
\text { прозорий } \\
\text { 3 голубим } \\
\text { відтінком }\end{array}$ & $\begin{array}{c}\text { м'ясний } \\
\text { бульйон } 3 \\
\text { крупними } \\
\text { пластівцями }\end{array}$ & $\begin{array}{c}\text { м'ясний } \\
\text { бульйон } \\
\text { прозорий } 3 \\
\text { незначним } \\
\text { помутнінням }\end{array}$ & $\begin{array}{c}\text { м'ясний бульйон } \\
3 \text { помутнінням } \\
\text { і крупними } \\
\text { пластівцями }\end{array}$ \\
\hline
\end{tabular}

(БГКП) на агарі Ендо та порівняли 3 нормативними значеннями які викладені у гігієнічному критерію технологічного процесу для м'яса і м'ясних продуктів [10] (таблиця 4).

Таблиця 4

Показники мікробного забруднення сировини

\begin{tabular}{|c|c|c|c|}
\hline \multirow[b]{2}{*}{$\begin{array}{c}\text { Вид сировини, } \\
\text { нормативні показники }\end{array}$} & \multicolumn{3}{|c|}{ Мікробіологічні показники } \\
\hline & $\begin{array}{l}\text { КМАФАнМ } \\
\text { (КУО), У 1г }\end{array}$ & $\begin{array}{c}\text { БГКП (КУО), } \\
\text { У 1г }\end{array}$ & $\begin{array}{c}\text { Сульфітредукуючі } \\
\text { клостридії в 0,01 гр }\end{array}$ \\
\hline Свинина охолоджена & $8,2 \times 10^{5}$ & $2,8 \times 10^{2}$ & Не виявлено \\
\hline Свинина дефростована & $2,2 \times 10^{6}$ & $4,5 \times 10^{2}$ & Не виявлено \\
\hline Припустимі рівні & $5,0 \times 10^{5}-5 \times 10^{6}$ & $50-5 \times 10^{2}$ & Не припустимо \\
\hline Гриби глива звичайна & $6,4 \times 10^{3}$ & Не виявлено & Не виявлено \\
\hline Припустимі рівні & $5,0 \times 10^{4}$ & $100-1000$ & Не припустимо \\
\hline Перець чорний & $1,3 \times 10^{3}$ & Не виявлено & Не виявлено \\
\hline Припустимі рівні & $\leq 1000$ & Не припустимо & Не припустимо \\
\hline Сіль & $4,8 \times 10^{2}$ & Не виявлено & Не виявлено \\
\hline Припустимі рівні & $\leq 1000$ & Не припустимо & Не припустимо \\
\hline Лавровий лист & $2,6 \times 10^{2}$ & Не виявлено & Не виявлено \\
\hline Припустимі рівні & $\leq 1000$ & Не припустимо & Не припустимо \\
\hline
\end{tabular}

Отримані дані свідчать, що охолоджене м'ясо, яке надходить для виробництва консервів, має мікробіологічні показники в межах норми. Дефростоване м'ясо за рівнем мікробного забруднення наближається до граничних допустимих меж, що пояснюється швидким розвитком мікрофлори після розморожування. Гриби які ми плануємо використовувати для виробництва даного виду консервів, під час прийому мають припустимі рівні мікробного забруднення, це стосується і іншої допоміжної сировини, за винятком чорного перцю. Однак, треба зазначити, що після перемішування всіх інгредієнтів буде проведено стерилізацію, яка при дотриманні режимів дозволить знищити вегетативні та спорові форми.

Оцінка готової продукції, а саме консервів «Свинина 3 грибами» проведена згідно прийнятим методам дослідження в умовах виробничої лабораторії підприємства і лабораторії контролю якості і безпечності харчових продуктів Херсонського державного аграрно-економічного університету. Визначено кислотне число, вміст м'яса, жиру (таблиця 5). 
Таблиця 5

Показники якості готової продукції

\begin{tabular}{|l|c|c|c|}
\hline \multicolumn{1}{|c|}{ Показник } & $\begin{array}{c}\text { Каша гречана } \\
\text { зі свининою }\end{array}$ & Варіант I & Варіант II \\
\hline Кислотне число, мг КОН/г & $1,07 \pm 0,02$ & $1,03 \pm 0,01$ & $1,04 \pm 0,01$ \\
\hline $\begin{array}{l}\text { Масова частка м'яса і жиру, } \\
\text { \% не менше }\end{array}$ & $60,0 \pm 0,4$ & $58,0 \pm 0,5$ & $48,0 \pm 0,4$ \\
\hline Масова частка жиру,\% не більше & $25,0 \pm 0,2$ & $22,0 \pm 0,3$ & $23,5 \pm 0,1$ \\
\hline Сторонні домішки & не виявлено & не виявлено & не виявлено \\
\hline
\end{tabular}

Проведені дослідження показують, що під час закладання компонентів м'ясна сировина була свіжою з відповідною якістю на що вказує кислотне число. Масова частка жиру становить не більше $25 \%$ для контрольного зразка і від 22 до 23,5\% для дослідних зразків, що є у межах нормативних показників.

Висновки й пропозиції. Проведений хімічний аналіз свинини і гливи звичайної які запропоновані при створенні м'ясних готових страв 3 рослинними компонентами, свідчить про добрий баланс між складовими нутрієнтами. Вуглеводи, клітковина яку містять гриби можуть компенсувати надмірну кількість жиру у свинині, утворивши полікомпонентний комплекс. За рахунок введення грибів частково задовольняється потреба у цинку і вітамінах групи В (B2,B3,B5, B6, В9), вітаміні Д, Е, біотині. Сенсорна та профільна оцінки розробленої продукції, свідчать про досить привабливі і гармонійні поєднання компонентів консерви у зразку №1, де вміст грибної сировини становить 23\%, а м’ясної - 65\%.

\section{СПИСОК ВИКОРИСТАНОӤ ЛІТЕРАТУРИ:}

1. Сычев П.А., Ткаченко Н.П. Грибы и грибоводство. Донецк : «Издательство Сталкер», 2003. 512 c.

2. Крайнюк Л.Н., Мячикова Н.И. Пищевая ценность и основные направления переработки культивируемых грибов вешенка. Прогресивні технології та удосконалення прочесів харчових виробництв : Збірник наукових праць. Ч. 1. Харків : ХДАТОХ, 2000. С. 21-26.

3. Літуєв Д.С., Фєдотов Д.В. Антиокисна активність деяких штамів їстівних грибів. Методологические основы познания биологических особенностей грибов продуцентов физиологически активных соединений и пищевых продуктов : материалы II международной конференции. Донецк, 2002. С. 128-131.

4. Дудка I.О. Гриби природних зон Криму. Київ : Фітосоціоцентр, 2004. 452 с.

5. Ястреба Ю.А. Вдосконалення технології грибного напівфабрикату і комбінованих м'ясних продуктів з його використанням : автореф. дис. ... канд. техн. наук : 05.18.16. Київ, 2018. 22 с.

6. Лялик А.Т., Криськова Л.П., Кравчук Л.О. Концепція функціональних харчових продуктів. Стан $і$ перспективи харчової науки та промисловості : тези доповідей Міжнародної науково-технічної конференції, м. Тернопіль, 24 травня 2017 р. Тернопіль, 2017. С. 114-115.

7. Стеценко Н.О. Функціональні харчові продукти у забезпеченні здоров'я людини. Die Relevanz und die Neuheit der modernen wissenschaftlichen Studien : der Sammlung wissenschaftlicher Arbeiten , $\Lambda \mathrm{O} О Г О \Sigma^{“} \mathrm{zu}$ den Materialien der internationalen wissenschaftlich-praktischen Konferenz, Wien, 23 August 2019. Wien : NGO „Europäische Wissenschaftsplattform“,. 2019. B. 3. S. 56-59.

8. Функціональні харчові продукти 3 наповнювачами / В.В. Власенко, М.М. Бондар, Т.В. Семко, А.М. Соломон. Техніка, енергетика, транспорт АПК. 2016. № 3 (95). C. 106-109. 
9. Скурихина И.М., Тутельяна В.А. Химический состав российских пищевых продуктов : Справочник. Москва : ДеЛи принт, 2002. 236 с.

10. Про затвердження Мікробіологічних критеріїв для встановлення показників безпечності харчових продуктів : Наказ Міністерства охорони здоров'я України від 19 липня 2012 р. № 548. Додаток II / Міністерство охорони здоров’я України. URL: https://zakon.rada.gov.ua/laws/show/z1321-12\#Text.

\section{REFERENCES:}

1. Sychev, P.A., Tkachenko, N.P. (2003). Hryby y hrybovodstvo [Mushrooms and mushroom growing] D.: "Yzd-vo Stalker". 512 p. [in Ukrainian].

2. Kraynyuk, L.N., Myachykova, N.Y. (2000). Pyshchevaya tsennost y osnovnye napravlenyya pererabotky kultyvyruemykh hrybov veshenka. [Nutritional value and main directions of processing of cultivated oyster mushrooms] Prohresyvni tekhnolohiyi ta udoskonalennya protsesiv kharchovykh vyrobnytstv: Zb. nauk. pr. CH.1. Kharkiv: KHDATOKH. 21-26 [in Ukrainian].

3. Lituyev, D.S., Fyedotov, D.V. (2002). Antyokysna aktyvnist deyakykh shtamiv yistivnykh hrybiv. [Antioxidant activity of certain strains of yeast fungi] "Metodolohycheskye osnovy poznanyya byolohycheskykh osobennostey hrybov - produtsentov fyzyolohychesky aktyvnykh soedynenyy y pyshchevykh produktov”. Materyaly II mezhdunarodnoy konferentsyy. Donetsk. 128-131 [in Ukrainian].

4. Dudka, I.O. (2004). Hryby pryrodnykh zon Krymu. [Mushroom natural areas of Krimu] K.: Fitosotsiotsentr. 452 p. [in Ukrainian].

5. Yastreba, YU.A. (2012). Vdoskonalennya tekhnolohiyi hrybnoho napivfabrykatu i kombinovanykh myasnykh produktiv $z$ yoho vykorystannyam avtoref. [Improving the technology of mushroom semi-finished products and combined meat products with its use]. Kyyiv. 22 p. [in Ukrainian].

6. Lyalyk, A., Kryskova, L., Kravchuk, L. (2017). Kontseptsiya funktsionalnykh kharchovykh produktiv. [The concept of functional foods] "Stan i perspektyvy kharchovoyi nauky ta promyslovosti": tezy dopovidey Mizhnarodnoyi naukovo-tekhnichnoyi konferentsiyi (24 travnya 2017) Ternopil. 114-115 [in Ukrainian].

7. Stetsenko, N.O. (2019). Funktsionalni kharchovi produkty u zabezpechenni zdorovya lyudyny. [Functional foods in human health]. Die Relevanz und die Neuheit der modernen wissenschaftlichen Studien : der Sammlung wissenschaftlicher Arbeiten "LÓHOS" zu den Materialien der internationalen wissenschaftlich-praktischen Konferenz, Wien, 23 August, 2019. Wien : NGO "Europäische Wissenschaftsplattform", 3, 56-59 [ in Austrien].

8. Vlasenko, V.V., Bondar, M.M., Semko, T.V., Solomon, A.M. (2016). Funktsionalni kharchovi produkty $\mathrm{z}$ napovnyuvachamy. [Functional food products with fillers] Tekhnika, enerhetyka, transport APK, 3 (95), 106-109 [in Ukrainian].

9. Skurykhyna, Y.M., Tutelyana, V.A. (2002) Khymycheskyy sostav rossyyskykh pyshchevykh produktov [Chemical composition of Russian food products]: Spravochnyk. DeLy print. 236 p. [in Russian].

10. Dodatok 2 do Mikrobiolohichnykh kryteriyiv dlya vstanovlennya pokaznykiv bezpechnosti kharchovykh produktiv. URL: https://zakon.rada.gov.ua/laws/show/ z1321-12\#Text [in Ukrainian]. 